\title{
Obesity and its Risk Associations in Older Mexicans Living with HIV
}

\section{Díaz-Ramos Julio Alberto1,*, Muñoz-Morales José Luis², Torres-Oregel Pamela Miroslava1', Velázquez-Izazaga Pedro², Garnés- Rancurello Sandra ${ }^{2}$, Fraga-Ávila Claudia ${ }^{3}$, González-Hernández Luz Alicia ${ }^{4}$, and Andrade-Villanueva Jaime ${ }^{4}$}

\author{
${ }^{1}$ Unidad de Atención Geriátrica de Alta Especialidad, Hospital Civil Fray Antonio Alcalde, Guadalajara, Jalisco, México \\ ${ }^{2}$ Tecnologico de Monterey, Escuela de Medicina y Ciencias de la Salud, Campus Guadalajara, Jalisco, México \\ ${ }^{3}$ Universidad del Valle de Atemajac, Guadalajara, Jalisco, México \\ ${ }^{4}$ Unidad de VIH, Hospital Civil Fray Antonio Alcalde, Guadalajara, Jalisco, México
}

*Corresponding author: Díaz-Ramos Julio Alberto, Unidad de Atención Geriátrica de Alta Especialidad, Hospital Civil Fray Antonio Alcalde, Guadalajara, Jalisco, C.P. 44280, México, Tel: (+052) 331761 1928; Fax: (33)36147748-36146988; E-mail: julio.alberto.diaz.ramos.geriatra@gmail.com

Received: 15 Oct, 2019 | Accepted: 11 Nov, 2019 | Published: 18 Nov, 2019

Citation: Díaz-Ramos JA, Muñoz-Morales JL, Torres-Oregel PM, Velázquez-Izazaga P, Garnés-Rancurello S, et al. (2019) Obesity and its Risk Associations in Older Mexicans Living with HIV. J HIV AIDS 5(3): dx.doi.org/10.16966/2380-5536.168

Copyright: (C) 2019 Díaz-Ramos JA, et al. This is an open-access article distributed under the terms of the Creative Commons Attribution License, which permits unrestricted use, distribution, and reproduction in any medium, provided the original author and source are credited.

\section{To the Editor}

It is expected that by 2020 , older adults living with HIV (OALHV) represents more than $50 \%$ of the population living with HIV worldwide [1,2]. It should be mentioned that some of them have aged with HIV and others have acquired the infection only in old age. In addition, OALHIV have a high risk for developing chronic diseases associated with age, but that occur earlier among people living with HIV, unlike those without the infection [3-5]. HIV infection causes premature aging and this seems to be caused by chronic immune activation as well as numerical loss and dysfunction of $\mathrm{CD} 4^{+}$cells. Others biological similarities between aging and HIV infection include DNA damage, loss of DNA repair capacity and altered mechanisms of apoptosis of immune system cells [6]. The increase in life expectancy and survival caused by advances in the treatment of HIV infection, resulted in an increase in the prevalence of some chronic diseases included obesity $[7,8]$.

Thus, a 2-year longitudinal study of 116 participants was conducted to determine the prevalence of obesity and its risk associations in OALHIV. The participants were adults over 50 years of age living with HIV and attending an HIV clinic in a university hospital in the city of Guadalajara in Mexico. Recruitment occurred between January 2015 and January 2017. All participants underwent a geriatric evaluation with which the diagnoses of geriatric syndromes were obtained. In accordance with convention, we defined obesity as BMI $\geq 30 \mathrm{~kg} / \mathrm{m}^{2}$. Correlates variables included age, sex, $\mathrm{CD} 4^{+}$count and some geriatrics syndromes. Frailty was defined according to phenotype proposed by Fried [5]. Depression was assessed using the Geriatric Depression Scale [3]. $\mathrm{CD}^{+} \mathrm{T}$-lymphocyte count $\left(\mathrm{CD}^{+}\right)$was measured by flow cytometry (BD FACSCalibur" ${ }^{\mathrm{rm}}$ ).

Multivariate logistic regression analyses were created to identify the socio-demographic and health correlates of obesity. The final model included sex, and the CD4 count, age at the time of HIV diagnosis and the presence of symptoms of depression were included as confounding variables. All statistical tests were performed using
95\% Confidence Intervals (CI) at the 0.05 level. Statistical analyses were conducted using the Stata statistical package for Windows (Stata Corp., Texas, IL., v. 14).

\section{Results}

The mean age of the participants was $57.59 \pm 7.8$, and $13.8 \%$ were obese. Participants with obesity were more likely to have a $\mathrm{CD} 4^{+}$ count $<200 \mathrm{cell} / \mathrm{mm}^{3}$ (75\%), and 50\% were woman. The presence of frailty and depression was $21.4 \%$ and $19.8 \%$ respectively. The logistic regression analysis showed a positive association between obesity and being a woman, independently of $\mathrm{CD}^{+}$, age at diagnosis of HIV and depression (OR 5.559, 95\% CI 1.753-17.63, $\mathrm{P}=0.004$ ) (Table 1).

\section{Discussion and Conclusion}

In this study, 16 participants were classified with obesity and half of them were women, however according to sex, 36.5\% of women classified as obese while the group of men only $7.3 \%(\mathrm{P}=0.001)$. Our work provides some interesting observations in the light of other studies $[7,8]$. One of them is the clear tendency in the group of women to show a higher frequency of geriatric syndromes. For example, all women with obesity had frailty as opposed to men (0\%). Also and statistically significantly, women were older than men at the time of HIV diagnosis ( $83 \%$ vs. $16 \%, \mathrm{P}=0.039$ ).

On the other hand, frequently, findings that demonstrate the existence of a trend are reported: the higher the leukocyte count, the greater the body mass index. However, not all studies have shown the same protective effect [9]. Our results add up to others, where women do not show the classic benefit association between BMI and CD4 count. In this work the frequency of CD4<200 in the group with obesity was $14.6 \%$, but the distribution was identical in both sexes $(\mathrm{P}=1)$. Similarly, the result of the logistic regression did not change even after adding the $\mathrm{CD} 4<200$ count to the multivariate analysis.

The increase in the prevalence of obesity in elderly women living with HIV can be explained by several mechanisms. One of them 
Table 1: Health characteristics according to sex in obesity.

\begin{tabular}{|l|c|c|c|}
\hline & $\begin{array}{c}\text { Woman } \\
\mathrm{n},(\%)\end{array}$ & $\begin{array}{c}\text { Male } \\
\mathrm{n},(\%)\end{array}$ & P-value \\
\hline Age ( $\mathbf{5 0}$ years) & $5(83.3)$ & $1(16.7)$ & 0.039 \\
\hline Frailty & $3(100)$ & - & 0.070 \\
\hline CD4+ count $<\mathbf{2 0 0} \mathbf{~ c e l} / \mathbf{m m}^{\mathbf{3}}$ & $6(50)$ & $6(50)$ & 1 \\
\hline
\end{tabular}

are the anatomical changes which are more pronounced in women than in men: decrease in total body water, expansion of the fatty compartment and decreased muscle and bone mass [6]. It's known that education plays an important role in the development of obesity. Thus, obesity decreases as the educational level increases in the elderly [10]. Although no statistically significant difference was found, there is a clear tendency in the group of women in this study to present lower levels of schooling compared to that of men. And of course, the survival effect observed in the distribution of gender in the age groups of old age is maintained in the context of HIV infection: there are more women living with HIV than men with the infection.

In summary, our study showed that women were more at risk of being obese. Women also showed some significant compared to men: they were older at the time of HIV diagnosis and all were frailty. In this study, the CD4 count did not show an association with BMI. Obesity seems to be a continuum in the clinical spectrum of HIV infection, in which the pathophysiological pathways of frailty and immunodeficiency converge-as in biological aging. Thus, obesity can be the consequence of particular forms of aging, the confluence of HIV infection and altered immunological performance. This is a preliminary study; the results should also be interpreted in light of the limitations of any cross-sectional study. Future studies should be longitudinal to determine if older people, especially women, living with HIV have a higher risk of obesity over time.

\section{Acknowledgements}

\section{Conflict of interest}

\section{None}

\section{Author contributions}

Muñoz-Morales, Torres-Oregel, Velázquez-Izazaga \& GarnésRancurello: analysis and interpretation of data, under the supervision of Dr. Díaz-Ramos. Fraga-Ávila \& Díaz-Ramos: Concept and design of the study, analysis and interpretation of data, writing the manuscript under the supervision of Drs. González-Hernández and Andrade-
Villanueva. The co-authors certify that they have participated substantially in the conceptualization and design of this work and the analysis of the data and the writing of the manuscript. They have reviewed the final version of the manuscript and have approved it for publication.

\section{Sponsor's role \\ None}

\section{References}

1. Centers for disease Control and Prevention (2008) HIV/AIDS among persons aged 50 and older. CDC HIV/AIDS facts.

2. Gebo KA, Justice A (2009) HIV infection in the elderly. Curr Infect Dis Rep 11: 246-254.

3. Avila-Funes JA, Zamudio-Rodriguez $A$, Muñoz-Nevárez LA, Belaunzarán-Zamudio PF, Diaz-Ramos JA, et al. (2018) Correlates of depressive symptoms among older adults living with HIV. Int J Geriatr Psychiatry 33: 1260-1264.

4. Diaz-Ramos JA, Asencio-del Real G, Fraga-Avila C, Leal-Moral D, Gonzalez-Hernandez LA, et al. (2018) Prevalence of frailty and its association with comprehensive geriatric assessment scores among older adults with HIV. J Lat Am Geriat Med 4: 13-18.

5. Diaz-Ramos JA, Fraga-Avila C, Asencio-del Real G, Leal-Mora D, Gonzalez-Hernandez LA, et al. (2018) Prevalence of Frailty and Association with the Immune Profile Among Older Adults with HIV at a University Affiliated Hospital. J HIV AIDS 4.

6. Díaz-Ramos JA, González-Hernández LA, Fraga-Ávila C, Asencio-del Real G, Piñeirúa-Menéndez $A$, et al. (2016) Nutritional issues in geriatric care: Nutrition and HIV. J Lat Am Geriat Med 2: 51-62.

7. Mankal PK, Kotler D (2014) From wasting to obesity, changes in nutritional concerns in HIV/AIDS. Endocrinol Metab Clin North Am 43: 647-663.

8. Thompson-Paul AM, Wei SC, Mattson CL, Robertson M, HernandezRomieu AC, et al. (2015) Obesity among HIV-infected adults receiving medical care in the United States: Data from de CrossSectional Medical Monitoring Project and National Health and Nutrition Examination Survey. Medicine 94: e1081.

9. Crum-Cianflone NF, Roediger M, Elberly LE, Vyas K, Landrum ML, et al. (2010) Obesity among HIV-infected persons: impact of weight on CD4 cell count. AIDS 24: 1069-1072.

10. Overweight and obesity-BMI statistics. Eurostat. 